AUTHOR CORRECTION

\title{
Correction: Blinatumomab in pediatric patients with relapsed/ refractory acute lymphoblastic leukemia: results of the RIALTO trial, an expanded access study
}

Franco Locatelli, Gerhard Zugmaier (D), Noemi Mergen, Peter Bader, Sima Jeha, Paul-Gerhardt Schlegel, Jean-Pierre Bourquin, Rupert Handgretinger, Benoit Brethon, Claudia Rossig and Christiane Chen-Santel

(c) The Author(s) 2021

Blood Cancer Journal (2021)11:173; https://doi.org/10.1038/s41408-021-00567-4

Correction to: Blood Cancer Journal https://doi.org/10.1038/ s41408-020-00342-x published online 24 July 2020

Following the publication of this article, the authors requested the following corrections:

Page 2: The sentence "Three of the four patients with constitutional trisomy 21 achieved CR with MRD response, two completed study in remission and were still alive at last follow-up". changed to "All four patients with constitutional trisomy 21 achieved CR with MRD response, two completed study in remission and were still alive at last follow-up".

Page 4: The sentence "Achievement of CR in three of four patients with constitutional trisomy 21 suggests that blinatumomab could be particularly useful to treat these fragile patients at risk of experiencing severe toxicities when exposed to aggressive chemotherapy." changed to "Achievement of CR in all four patients with constitutional trisomy 21 suggests that blinatumomab could be particularly useful to treat these fragile patients at risk of experiencing severe toxicities when exposed to aggressive chemotherapy".

The authors confirm no change to the conclusions of the article.

\begin{abstract}
(c) (i)
Open Access This article is licensed under a Creative Commons Attribution 4.0 International License, which permits use, sharing, adaptation, distribution and reproduction in any medium or format, as long as you give appropriate credit to the original author(s) and the source, provide a link to the Creative Commons license, and indicate if changes were made. The images or other third party material in this article are included in the article's Creative Commons license, unless indicated otherwise in a credit line to the material. If material is not included in the article's Creative Commons license and your intended use is not permitted by statutory regulation or exceeds the permitted use, you will need to obtain permission directly from the copyright holder. To view a copy of this license, visit http://creativecommons. org/licenses/by/4.0/.
\end{abstract}

C The Author(s) 2021 